\title{
The Brewer, the Baker, and the Monopoly Maker*
}

\author{
Diana W. Thomas ${ }^{\dagger} \quad$ Peter T. Leeson ${ }^{\ddagger}$
}

\begin{abstract}
This paper examines how productive entrepreneurial activities, such as innovation, influence unproductive entrepreneurial activities, such as regulatory rent seeking. We argue that the former may increase the latter. Confronted with a situation in which innovation erodes their monopoly returns, legally protected producers and policymakers reregulate industry to recapture lost rents. Regulation policy under such reregulation tends to be more encompassing, and thus produces more unproductive entrepreneurial activity, than preinnovation regulation policy. This reflects the greater number or variety of producers that new regulation policy must encompass for reregulation to recreate rents. To investigate our argument we consider Bavaria's brewing industry in the $14^{\text {th }}$ through $16^{\text {th }}$ centuries.
\end{abstract}

\footnotetext{
* Leeson thanks the Mercatus Center at George Mason University for financial support.

† Email: Diana.Thomas@USU.edu. Address: Utah State University, Department of Economics and Finance, 3565 Old Main Hill, Logan, UT 84322-3565.

‡ Email: PLeeson@GMU.edu. Address: George Mason University, Department of Economics, MS 3G4, Fairfax, VA 22030.
} 


\section{Introduction}

How do productive entrepreneurial activities, such as innovation, affect unproductive ones, such as regulatory rent seeking? ${ }^{1}$ Productive and unproductive entrepreneurship clearly influence one another. For example, productive entrepreneurial activity that creates additional wealth increases the payoff of political maneuvering that expropriates wealth. This is one very simple way in which productive entrepreneurial activity can affect unproductive entrepreneurial activity. There are many others.

Despite this, almost no work has examined the potential channels of influence between kinds of entrepreneurship. One important exception is Diana Thomas' (2009) work on entrepreneurial innovation and the transitional gains trap. Thomas argues that productive entrepreneurial innovation not only benefits society directly. It may also benefit society indirectly by reducing unproductive entrepreneurial activity manifested through regulatory rent seeking.

According to Thomas, innovation by legally unprotected producers in an industry can erode the monopoly rents that legally protected producers in that industry enjoy. If innovation erodes protected producers' rents sufficiently, it can undermine their support for the existing regulatory policy that protects them. ${ }^{2}$ In this way innovation can be a powerful force driving deregulation, and thus a powerful force driving a reduction in unproductive entrepreneurial activities associated with regulatory rent seeking. ${ }^{3}$

\footnotetext{
${ }^{1}$ The productive/unproductive entrepreneurship distinction was first made by Baumol (1990). Leeson and Boettke (2009) discuss a different entrepreneurial-form distinction based on entrepreneurship within social rules and entrepreneurship over social rules.

${ }^{2}$ McChesney (1987: 101) also makes the point that innovation may "render existing government regulations undesirable to their prior beneficiaries."

${ }^{3}$ As Thomas argues, in this way innovation also permits a solution to Tullock’s (1975) transitional gains trap.
} 
Our paper builds on Thomas' (2009) important insight. But it identifies an alternative channel through which productive entrepreneurial innovation may influence unproductive entrepreneurial rent seeking — one with less optimistic welfare implications than the channel she identifies. We argue that productive entrepreneurial innovation by legally unprotected producers in an industry can also increase, rather than decrease, the extent of unproductive entrepreneurship in that industry. ${ }^{4}$ Confronted with a situation in which innovation erodes their monopoly returns, legally protected producers and policymakers may reregulate industry to permit them to recapture lost rents.

Regulation policy under such reregulation tends to be more encompassing, and thus produces more unproductive entrepreneurial activity, than pre-innovation regulation policy. This reflects the greater number or variety of producers that new regulation policy must encompass for reregulation to recreate rents. Although deregulation is one possible response to productive entrepreneurial innovation that erodes existing regulatory rents, reregulation is another.

The reregulation response comports better with the theory of regulatory capture than the deregulatory one. Once an industry is regulated, industry insiders, politicians, and bureaucrats have incentives to respond to threats to their rents through reregulation that renews their ability to earn rents through politically enforced restrictions governing the industry. These groups will only prefer deregulation when reregulation is so costly for them to create that they expect larger net payoffs under a regime of market competition than under a regime of protection from such competition.

Besides Thomas (2009), our argument is most closely connected to Benson’s (2002) excellent study that considers the regulation and then (partial) deregulation of the interstate

\footnotetext{
${ }^{4}$ Kirzner $(1973,1997)$ discusses the productive entrepreneurial process. Coyne, Sobel, and Dove (2010) discuss the unproductive entrepreneurial process.
} 
trucking industry in the United States. Benson points out that trucking regulation initially benefited producers in that industry. However, it ultimately became so costly to comply with that many members of the industry decided they would do better if policymakers dismantled the existing regulatory regime instead. The ensuing “deregulation” involved considerable reregulation as producers sought to reform regulatory policy in a way that eliminated many of its costly aspects that damaged their interests but retained or enhanced aspects that would (re)create rents for them.

Our argument shares with Benson's the idea that eroded rents create pressure for regulatory change. However, the source of eroded rents our argument emphasizes is different: they come from productive entrepreneurial activities rooted in innovation instead of from higher regulatory compliance costs. Further, our argument suggests that reregulation driven by productive entrepreneurial activities creates a regulatory regime with more scope-encompassing more producers, a wider territory, or both—since new regulatory policy must encompass additional producers, in particular producers of substitutes created via innovation. Reregulation responding to productive entrepreneurial activity therefore tends to lead to increased unproductive entrepreneurial activity compared to that which prevailed under the previous regulatory regime.

To investigate our argument we consider Bavaria's brewing industry in the $14^{\text {th }}, 15^{\text {th }}$, and $16^{\text {th }}$ centuries. Leading up to the $15^{\text {th }}$-century, guild brewers in Bavaria's cities enjoyed extensive legal protection from countryside brewers that permitted them to earn monopoly rents. However, an innovation by countryside brewers in the form of hops-brewed beer, which spread to the cities in the late $14^{\text {th }}$ century, quickly eroded those rents.

Munich's brewers responded to rent erosion by lobbying both the duchy and the city government for reregulation that would recreate rents for their guild. Reregulation provided an 
opportunity to tax the wealthy brewers. This created a struggle between the city and the duchy government over who would enforce, and thus reap the benefits of, reregulation. Both levels of government passed new guild charters throughout the $15^{\text {th }}$ century. But these charters failed to solve the brewers' guild's problems and provide a stable source of government revenue.

A new (re)regulatory policy that benefited all parties was finally found in the early $16^{\text {th }}$ century. That policy took the form of a duchy-wide regulatory regime that encompassed a much larger region and wider variety of brewers that included country and city producers. This reregulation was called the Purity Law.

Beer reregulation under the Purity Law massively expanded, rather than constricted, regulation in the brewing industry, concomitantly expanding, rather than contracting, the scope for unproductive entrepreneurial activity in the form of regulatory rent seeking. The creation of the Purity Law of 1516 was the result of unproductive entrepreneurial activity on the part of city brewers, country brewers, city bakers, and public officials, all of whom sought to influence reregulation prompted by the productive entrepreneurial innovation of hops-brewed beer. In establishing a new, much wider-reaching regulatory regime, the Purity law created an environment conducive to more regulatory rent seeking.

\section{Making Monopoly}

Hops are a standard ingredient in the production of modern beer. But in the late Middle Ages they weren't. In most regions of the Holy Roman Empire brewers made their beer without hops. Instead they used spice mixtures to flavor their beer. In addition to giving even unspoiled beer a pleasant taste, these spice mixtures helped brewers hide the unpleasant flavor of beer that had gone bad. 
Bad beer was a serious problem in the Middle Ages. Artificial preservatives hadn't been invented yet, nor had refrigeration. Medieval brewers attempted to improve their drink's preservability by brewing beer with high alcohol content. This contained bacterial growth somewhat. But its helpfulness in preserving beer was limited. Because of this, beer distribution in medieval Germany was restricted to small geographic areas emanating from the place of production.

Despite the lack of hops, the medieval brewing process was similar to that process today. First brewers would poor hot water over malted grain to extract its vegetable matter. The resulting mixture was called mash. Next they would separate the liquid, or wort, from the solid parts of the mash. Brewers then boiled the wort together with spices. Finally they fermented the wort-spice mix with yeast. The result was a carbonated, alcoholic beverage: beer. ${ }^{5}$

The spice mixtures brewers combined with their wort included bog myrtle, rosemary, anise, ginger, chaff, and cumin. Each region or city had its own distinctive spice mixture, called grut. Grut recipes were closely guarded secrets of their respective brewers' guilds. They gave each city's beer a distinctive flavor.

In the $11^{\text {th }}$ century the Holy Roman Emperor awarded regional monopoly privileges, called Grutrecht, over the production and sale of grut to duchies and dioceses throughout the empire. ${ }^{6}$ Thomas (2009) argues that these privileges were awarded to different groups in exchange for their support of the emperor in the investiture controversy with the papacy. As a result, some of these duchies and dioceses became monopoly producers of beer. Others sold the privilege to local brewers' guilds in exchange for tax or licensing benefits, which we describe below.

\footnotetext{
${ }^{5}$ See Unger (2004: 4) for a complete description of the medieval brewing process.

${ }^{6}$ Von Blanckenburg (2001: 174) describes the areas in which such monopoly privileges were awarded.
} 
Grut privileges generated significant income for their holders. Beer was the most popular beverage at the time. Licensed brewers' guilds enjoyed exclusive production and sale rights of this beverage in their cities, precluding competition from other brewers in their cities and countryside brewers. This allowed guild brewers to charge monopoly prices and earn monopoly rents.

Grut monopolies also generated important financial benefits for the licensing diocese or duchy. Grut-privilege licensors enjoyed fees from the sales of licenses to city brewers that protected their monopolies. A perusal of various city records from the High Middle Ages attests to the large tax revenues and related licensing fees that grut monopolies created for their suppliers. ${ }^{7}$

In $14^{\text {th }}$ - and $15^{\text {th }}$-century Bavaria the duke was the Grutrecht holder. He awarded brewing rights to a small number of brewers' guilds in Bavarian cities. The privileged guilds made annual payments to the duke in return for the right to brew beer. Distinct grut mixtures allowed guild members to distinguish their beer from beer non-guild members brewed. Because the guilds' legal protection prohibited the sale of beer made by non-licensed brewers in Bavarian cities, guild beer commanded a higher price—one high enough to create revenues to pay the duke's licensing fee and leave something left over for the brewers.

\footnotetext{
${ }^{7}$ See, for example, the city records for Cologne, republished in Loesch (1907: 59) and translated in Thomas (2009).
} 


\section{Unraveling Rents}

In the $15^{\text {th }}$ century productive entrepreneurial innovation pioneered by countryside brewers penetrated Bavarian cities together with the rest of the empire. ${ }^{8}$ That innovation was hops. Hops, which replaced grut in the brewing process, were a critical invention for the brewing industry. They were cheaper than grut. They prolonged beer's preservation compared to what brewers could achieve with grut. And, because of this, they permitted brewers to exploit another productive entrepreneurial innovation — the copper brewing kettle - which made brewing in much larger quantities possible.

Yet from the perspective of brewers' guilds there was a clear drawback to hops: they undermined their ability to restrict competition. In doing so hops undermined city brewers' ability to reap monopoly rents from competitive protections and thus the duke's ability to collect licensing revenues.

Unlike beer brewed with grut, which tasted different depending on the particular mix of spices used to produce it, there was nothing distinctive about beer brewed with hops. Before they began using hops, brewers could identify beer guild members made by its taste. Beer that didn’t taste “right” was the product of unlicensed brewers who weren’t part of the city's guild. The ease of detection allowed the guild to identify and punish illicit sellers. That in turn deterred brewers who weren't part of the city's guild from trying to circumvent the guild's legal protections. Further, the centralized production and distribution of grut allowed the guild to monitor and

\footnotetext{
${ }^{8}$ The literature is unclear about the exact timing of the adoption of hops as a beer ingredient. Teich (2000: 17) suggests that in Bavaria hops replaced grut beer sooner than elsewhere and was used in some monasteries as early as the $10^{\text {th }}$ century. For city brewing, however, the adoption of hops seems to have come later even in Bavaria. HackelStehr (1987) suggests that brewers in Munich started using hops towards the end of the $15^{\text {th }}$ century, which resulted in the feud between bakers and brewers we describe below.
} 
restrict its members' output. It was hard for members to produce more than their allotted quantity of grut-brewed beer. So grut-brewing fortified their cartel.

Hops-brewed beer was different. It tasted nearly the same no matter who produced it or where they did so. Further, hops weren’t centrally produced or distributed. This made monitoring and enforcing guild brewers’ production restrictions against non-guild brewers, and one another, in the presence of hops much more difficult.

Compounding the prospective difficulty of monitoring and enforcing a prohibition on the sale of non-guild beer in the presence of hops was an incentive incompatibility in government. In Munich the city council, not the Duke of Upper Bavaria, was responsible for overseeing the beer market. This meant the city council, not the duke, was responsible for enforcing the prohibition on beer brewed by non-guild members. However, the duke alone enjoyed licensing revenues from guild members' monopoly-priced beer. So the city council's incentive to enforce the brewers' guild's monopoly protections was weak.

Under the grut-regulation regime, misaligned government incentives did little to undermine Munich guild brewers' ability to protect their monopoly privilege and monitor each other's output. The particular grut those brewers used to brew their beer gave their beer a distinctive flavor. Even if city government officials were wont to keep countryside beer out of city markets or enforce production restrictions on guild members, city brewers could do so themselves. The hops innovation precluded this possibility.

The difficulties of enforcing their cartel in the face of countryside competitors and shirking guild members didn’t stop city brewers from trying to do so at first. Brewers' guilds all over Germany initially responded to the new competitive pressures with extensive efforts to keep hops-brewed beer out of their domains. Ultimately, however, the significant benefits of adopting 
the hops innovation proved too alluring for brewers' guilds. Those benefits trumped the costs of foregoing protection under the grut-regulation regime. So city guilds gave up their protection and switched to hops. Following this switch, the number of brewers operating in Munich's city limits ballooned. ${ }^{9}$

The result of city brewers' reversed attitude toward the existing regulation policy of their industry wasn't deregulation and a concomitant reduction in unproductive political entrepreneurship, however. It was reregulation-a new regulatory policy that would recreate rents for city brewers and government by protecting the former from competition in a different way.

\section{Recreating Rents}

The productive entrepreneurial activity that created the hops-brewing innovation drove the destruction of the existing regulatory policy centered around grut. But in doing so it created new problems for guild brewers and government. Abolishing the former regulatory policy enabled guild brewers to capitalize on the superior brewing technology of hops. But it abolished their ability to earn regulatory rents. Hops left the guild's brewers unprotected from countryside competitors and unable to maintain their own cartel. And, unprotected, beer prices weren't high enough to permit city brewers to pay their licensing fees to the duke.

Munich’s guild brewers sought a new regulatory regime that would let them recapture their lost rents. Eager to reclaim his own lost rents, the duke was happy to help them. In 1373 the duke passed a new guild charter permitting new brewers to join the brewers' guild. There was a catch

\footnotetext{
${ }^{9}$ Hackel-Stehr (1987: 31) reports that the ratio of citizens to brewers decreased dramatically between 1372 and 1502, falling from 536 to 346 citizens per brewer.
} 
for the new brewers, however. They weren't allowed to own brewing equipment or brew houses. They had to brew their beer in others' brew houses using others' equipment and pay those others—-who happened to be the old brewers' guild members—-for the privilege to do so. New brewers also had to pay a licensing fee to the duchy.

The new guild charter partially restored old brewers’ guild members' monopoly position, and the duke's precious licensing fees, albeit in a modified fashion. But it failed to address another problem that emerged when Munich’s brewers began using hops instead of grut to brew their beer.

In $14^{\text {th }}$-century Munich guild brewers not only enjoyed a legal monopoly on beer production. They also enjoyed a legal monopoly on the sale of yeast to bakers. Yeast is a natural byproduct of the brewing process. And the brewers' guild had used its political clout to get government to pass a law that required bakers to purchase their yeast exclusively from them.

Grut-brewed beer made for fine yeast. Hops-brewed beer didn't. Yeast derived from hopsbrewed beer gave the bakers' bread an unpleasant bitter flavor. The bitterness of hops transferred to the yeast during the brewing process. That bitter taste transferred to the bread when the bakers made bread with it (Hackel-Stehr 1987: 49-50). The bakers were unhappy. Their bitter bread was a hard sell in the face of competition from bread baked in the country where bakers weren't required to use the yeast city brewers supplied but could produce their own instead. Soon after the hops innovation penetrated Munich, city bakers began defying their legally mandated arrangement with city brewers. Bakers' defiance posed a new threat to the guild brewers' privileged position in the city.

To resolve their problem with Munich's bakers, the brewers again sought the duke's assistance. Unfortunately for the brewers, the duke wasn’t particularly interested in helping them 
this time around. Shortly after introducing the guild charter in 1373, the duke temporarily sold his right to brewing license fees. The brewers' licensing payments had been a significant and stable source of revenue for the duchy. So, when it faced severe revenue shortages in the $14^{\text {th }}$ and early $15^{\text {th }}$ century, the duke sold his right to collect those payments. Having pawned his future revenue streams from the brewers, the duke was less inclined to fight against the baker-initiated erosion of the brewers' monopoly rents. He no longer received licensing fees from the brewers. So he had little incentive to help them preserve their monopoly position.

Unable to obtain the duke's help, the brewers turned to the city council. Lured by the new potential to extract tax revenue from Munich's brewers, the city council responded by passing a new guild charter in 1453. That new charter reinforced bakers' obligation to buy yeast from guild brewers. But it also regulated brewing ingredients and set standards for yeast quality. ${ }^{10}$ The brewers liked this because it raised the cost of entering the city brewing market further, helping to restrict competition and, in doing so, contributed to their ability to recapture hops-eroded monopoly rents. The combination of better ingredients and higher quality yeast made the idea of being forced to buy the brewers' hops-based yeast sound more palatable to the bakers too.

The new guild charter also benefited the city council. Indeed, this is why the city council enacted it in the first place. To enforce the charter's new standards, brewers had to subject their brews and yeast to council-required inspections. These inspections weren't free, of course. Brewers had to pay the city council for them. Thus the charter created a new source of revenue for the city. ${ }^{11}$

\footnotetext{
${ }^{10}$ Hackel-Stehr (1987: 33) dates the enactment of the purity passage, which was part of the guild charter, between 1453 and 1487.

${ }^{11}$ Hackel-Stehr (1987: 316ff) describes the collection of inspection fees in different Bavarian cities.
} 
Besides regulating brewing, the 1453 charter also tried to recreate some of the rents the city's original guild brewers enjoyed under the old regulatory policy by controlling beer's price and its production process (Hackel-Stehr 1987: 35). Hackel-Stehr (1987) suggests the city council included these rules to gain jurisdictional authority over the brewers, which, officially, still resided with the duke. Other Bavarian cities facing similar competitive pressures from hopsbrewed beer produced in the countryside responded similarly, banning the use of additives in brewing, and later restricting legal beer ingredients to barley, hops, and water (Hackel-Stehr 1987: 201). ${ }^{12}$

What at first seemed like a tidy reregulatory solution to the brewer-baker problem and the city's desire to raise more revenue turned out to be objectionable from everyone but the city council's perspective. Although new beer and yeast standards raised the cost of entering the brewing market, brewers weren't keen on paying for council-required inspections. And even higher-quality hops-based yeast proved inferior from the bakers’ perspective, prompting them to circumvent the law requiring them to purchase their yeast from the brewers.

Between 1481 and 1517 Munich’s brewers and bakers clashed constantly over the brewers’ monopoly privilege in the provision of yeast. Unhappy with their respective situations, both groups continued to seek government support for their cause. Amidst this struggle the duke's political entrepreneurial foresight alerted him to benefits he thought he could reap down the road if he could regain some of the control over the brewers he had lost to the city council in the preceding years. The duke responded by issuing his own guild charter for the brewers in 1485/87. Unfortunately for the brewers and the bakers, this charter proved very similar to the

\footnotetext{
${ }^{12}$ Date when inclusion of additives is prohibited and date when legal ingredients are restricted to water, barley, and hops) in different Bavarian cities: Landshut $(1486,1493)$, Ingolstadt $(-, 1513)$, Straubingen (second half of the $15^{\text {th }}$ century, early $16^{\text {th }}$ century), Regensburg $(1457,1469)$.
} 
city's charter from 30 years before. It kept ingredient and yeast controls in place and reasserted brewers' right to force their yeast on bakers. Thus, like its predecessor, the duchy's new charter failed to resolve the brewer-baker conflict. It did, however, permit the duke to reassert his authority over the guild against the city council, which, as we discuss below, proved to be an important victory for him.

In yet another attempt to quell the brewer-baker feud, the duchy added a new provision to the brewers' guild charter in 1508 that distinguished between yeast from top-fermented beer and yeast from bottom-fermented beer. The new provision came closer than the two previous reregulatory regimes to addressing the bakers' complaint and to restoring the brewers' yeastbased regulatory rents. Bottom-fermented beer tends to be more hops intensive than topfermented beer. Thus the yeast used in the former's production tends to be bitterer. By limiting the brewers' yeast privilege to yeast from top-fermented brewing, this new rule assuaged the bakers' concerns.

In 1506 Upper and Lower Bavaria united under Duke Albert IV. That year Albert instituted a primogeniture rule to prevent a renewed division of the duchy (Stevens 1706: 89). Despite efforts to keep the duchy united, soon after Albert's death, Albert's son, Wilhelm IV, found himself in position in which he had to share his power with his younger brother, Ludwig X. The brothers came to an agreement over the administration of the duchy, which they drafted in Ingolstadt in 1516. They would keep the duchy united legally but divide it into two units administratively.

The dukes' agreement created an opportunity for them to resolve the lingering competition problem their city brewers faced, benefiting the brewers through total protection against competition, as they had protected them under the grut-regulation policy, while at the same time 
benefiting the dukes by ensuring the brewers were able to pay the high licensing fees for the brewing privilege, which they enjoyed under the old regime. The dukes' agreement also gave them a chance to finally and totally satisfy the disgruntled city bakers. The two brothers were quick to seize this opportunity. They added an important passage to their agreement: the Bavarian Purity Law of 1516.

The section of the Bavarian legal code that created the Purity Law contained six subsections regulating different aspects of the brewing industry. The first subsection regulated beer prices. It imposed price ceilings (brewers weren't allowed to charge more than 1 pfennig between September and April, and not more than 2 pfennig from May until August). Superficially this suggests consumer protection as a motivation. However, as Stigler (1971: 5) points out, price ceilings are often passed in the interest of producers with the aim of restricting entry by lowering expected returns from entering an industry, which was likely their intention here.

The second subsection of the code restricted brewing ingredients to barley, hops and water, as earlier attempts at reregulation required. Subsection 3 regulated the resale of beer bought from brewers. The Bavarian Landtag—the legislative assembly of the nobility—added a fourth subsection in 1520, which regulated price differentiation by region in case of regional changes in grain prices. Subsections 5 and 6 mandated that no new taverns or breweries would be allowed to open. Subsection 6 emphasized this competitive restriction and belied the genuine purpose of reregulation under the Purity Law by stipulating that all countryside breweries that had been in business for less than a decade were to close their doors.

Unlike previous stabs at reregulating the brewing industry, the Purity Law applied to the whole of Bavaria, bringing countryside producers into its orbit. The unification agreement and its attendant Purity Law reflected expert political entrepreneurship on the part of Wilhelm and 
Ludwig. It allowed them to extend their power to regulate and extract rents over the previously unregulated brewing industry in the countryside. This extension of political power reregulated the brewing industry in Bavarian cities, recreating monopoly rents for city brewers and enabling them to pay licensing fees to the dukes. It also aligned the previously misaligned incentives in the upper duchy's government that divorced the responsibility for enforcing brewing regulations, which formerly resided with city governments, from the licensing privileges associated with that enforcement, which formerly resided with the duke. Under the 1516 law the duke gained authority for market oversight and quality control, which now allowed him to enforce the regulation that protected guild members from countryside competition throughout the entire duchy. Munich’s city council lost all control rights over the brewers.

Reregulation under the Purity Law resolved government's problem with the cities' angry bakers, too. Under the 1516 law Wilhelm granted Munich’s bakers the right to produce their own yeast. This was undoubtedly less than ideal from brewers' perspective. But Wilhelm must've been pleased to secure the bakers' support. And it was a small concession for Munich's brewers to make in exchange for new, draconian restrictions on entry in their industry that totally foreclosed direct competition from new producers by limiting breweries and taverns to those already in existence, and shut down much of the greatest threat—-the countryside producers who were less than 10 years old. Munich's brewers enjoyed strengthened restrictions on competition and did so without having to pay inspection fees to the city council. They could no longer force their bitter yeast on the bakers. But they had little to complain about.

Reregulation, which encompassed the whole of Bavaria, increased the scope for unproductive entrepreneurial activity manifested through regulatory rent seeking. It brought a much larger territory under government's regulatory scope, adding, most notably, the Bavarian 
countryside. Similarly it brought many new producers under that scope, namely countryside brewers. Countryside brewers, whose productive entrepreneurial innovation through hops made them effective competitors of formerly protected city brewers, produced substitutes for citybrewed beer, undermining the latter's monopoly rents. Recreating those rents through reregulation therefore required a new regulation policy that encompassed the countryside and its brewers to be effective. Regulation had to be expanded in the face of the new brewing technology to permit members of the brewing industry to realize monopoly rents. So this is precisely what reregulation under the Purity Law did.

\section{Concluding Comments}

In an ironic twist of fate, contemporary German brewers-in an act of productive entrepreneurship —use the Purity Law of 1516-a product and facilitator of unproductive entrepreneurship—as an advertising tool to help them sell beer. ${ }^{13}$ Thus we come full circle and, in doing so, find yet another channel through which productive and unproductive entrepreneurial activity influence one another. German beer imports proudly display the slogan "Brewed according to the German Purity Law of 1516” on their labels. ${ }^{14}$ And the Bavarian Brewers League boasts on its website that the Purity Law’s original intent was to protect consumers. ${ }^{15}$

As this paper shows, the actual purpose of the Purity Law was quite different. It reflected unproductive entrepreneurial regulation efforts to recreate rents for city-based guild brewers and

${ }^{13}$ The purity law survived until 1987 when the European Court of Justice judged it to be in violation of the principle of free circulation of merchandise in the Union. See case \#178/84 of the European Court of Justice for details on this decision.

${ }^{14}$ See, for example, the label of Warsteiner pilsner imported to the US and information on the company's US web-site: http://www.warsteiner-usa.com/product.jsp.

${ }^{15}$ See http://www.bayerischerbrauerbund.de/contentserv/bayerisches-bier.de/index.php?StoryID=1893. 
government in Bavaria after productive entrepreneurial activity by countryside producers innovated hops brewing, eroding the existing regulation policy's power to generate rents for them. The Purity Law harmed consumers rather than protecting them. And when contemporary German brewers use the 1516 law to advertise their product they're unwittingly advertising political plunder rather than the purity of their beer.

Our analysis of how productive entrepreneurial activity, namely innovation, can affect unproductive entrepreneurial activity manifested in regulatory rent seeking leads to several conclusions. First, productive entrepreneurial innovation by producers who don't enjoy legal protection from competitors can erode the monopoly rents of producers in their industry who do enjoy such protection. This was clearly the case for Bavaria's city-based guild brewers in the $15^{\text {th }}$ century. Countryside producers who innovated hops revolutionized the brewing industry by creating a product so superior to the existing version that even producers of that version who benefited from government privilege found it profitable to give up their privilege so that they could take advantage of hops.

Second, though such a situation—when protected producers no longer benefit from protection—could lead policymakers to respond by simply deregulating the industry, that response is unlikely. A more likely response is that policymakers will work with members of the industry to reregulate the industry for their mutual benefit. Deregulation is probable only if producers and policymakers stand to benefit more by a genuine dismantling of the regulatory apparatus than they do if they reform that apparatus in a way that recreates their rents. Sixteenthcentury Bavaria clearly reflects the situation in which reregulation was more profitable. In response to competitive pressure from hops-brewed beer that undermined the grut regulation's 
effectiveness, guild brewers and government developed a new regulatory policy that allowed them to recreate at least some of the rents the grut regime bestowed on them before its demise.

Finally, our analysis suggests that new regulatory policy created to replace old regulatory policy in the face of eroded rents is likely to reflect and contribute to more unproductive entrepreneurial activity manifested in regulatory rent seeking than the old regulatory policy did. For reregulation to recreate lost rents it must envelop a wider range of producers—in particular those whose innovation undermined the old regulatory policy's effectiveness. This brings a larger number and wider array of producers within the new regulatory policy's ambit, which in turn creates a larger number of regulatory players who have an interest in undertaking unproductive political entrepreneurship to affect the distribution of wealth under the new policy and creates potentially higher payoffs from engaging in such activity. In the case of Bavaria's brewing industry, such an expansion of regulatory scope under reregulation is precisely what we observe. $^{16}$ The 1516 Purity Law encompassed countryside producers and new city-based producers, in addition to old city-based ones, and extended to rural territories in addition to urban ones.

This finding suggests that gauging the welfare effects of productive entrepreneurial innovation may not be as straightforward as is often thought. Thomas' (2009) study implies that in focusing only on the direct benefits that productive entrepreneurial innovation produces economists may be understating the positive welfare effects of such innovation: we should also

16 Peltzman (1989) provides a modern example of an expansion of regulatory scope following innovationdriven reregulation. Rail regulation in the United States existed since congress passed the Interstate Commerce Act in 1887. The original regulatory regime came under pressure, however, when the highway system and trucking became a more viable alternative for long-haul goods trafficking in the 1920s. As a result, existing regulatory rents eroded. As Peltzman (1989: 22) points out, "the first line of defense [against this rent erosion] was to bring the trucks under the regulatory tent in 1935." 
consider the unproductive entrepreneurship-reducing effects that productive entrepreneurial innovation may bring.

Our analysis suggests the reverse. In some cases at least, economists may be overstating the positive welfare effects of productive entrepreneurial innovation by focusing exclusively on its direct benefits. Such innovation may also lead to reregulation that's more comprehensive, and thus more conducive to regulatory rent seeking, than that which prevailed before it. A fuller accounting of productive entrepreneurial innovation's welfare effects would therefore require us to deduct the additional social losses that such greater rent seeking creates, rather than adding social benefits from a reduction in rent seeking. 


\section{References}

Baumol, William J. 1990. “Entrepreneurship: Productive, Unproductive, and Destructive.” Journal of Political Economy 98: 893-921.

Benson, Bruce L. 2002. "Regulatory Disequilibrium and Inefficiency: The Case of Interstate Trucking.” Review of Austrian Economics 15: 229-255.

Coyne, Christopher J., Russell S. Sobel, and John A. Dove, J. 2010. “The Non-Productive Entrepreneurial Process.” Review of Austrian Economics, forthcoming.

Hackel-Stehr, Karin. 1987. Das Brauwesen in Bayern: vom 14. Bis 16. Jahrhundert, insbesondere die Entstehung und Entwicklung des Reinheitsgebotes (1516). Berlin: Technische Hochschule Dissertation.

Huntemann, Hans. 1970. Bierproduktion und Bierverbrauch in Deutschland vom 15. bis zum Beginn des 19. Jahrhunderts. Goettingen: Wirtschafts- und Sozialwissenschaftliche Fakultaet Dissertation.

Kirzner, Israel M. 1973. Competition and Entrepreneurship. Chicago: University of Chicago Press.

Kirzner, Israel M. 1997. "Entrepreneurial Discovery and the Competitive Market Process: An Austrian Approach.” Journal of Economic Literature 35: 60-85.

Leeson, Peter T. and Peter J. Boettke. 2009. “Two-Tiered Entrepreneurship and Economic Development.” International Review of Law and Economics 29: 252-259.

McChesney, Fred S. 1987. "Rent Extraction and Rent Creation in the Economic Theory of Regulation.” Journal of Legal Studies 16: 101-118.

Peltzman, Sam. 1976. “Toward a More General Theory of Regulation.” Journal of Law and Economics 19: 211-240

Stevens, John. 1706. The History of Bavaria, from the First Ages, to this Present Year 1706. London: S. Ballard.

Stigler, George J. 1971. “The Theory of Economic Regulation.” Bell Journal of Economics and Management Science 2: 3-21.

Thomas, Diana W. 2009. “Deregulation Despite Transitional Gains.” Public Choice 140: 329340.

Tullock, Gordon. 1975. “The Transitional Gains Trap.” Bell Journal of Economics 6: 671-678. 